DOI: 10.11606/issn.2238-3867.v16i2p345-368

sala preta

ppgac

Dossiê Sobre a Cia. Brasileira

\title{
Troca de e-mails entre Marcio Abreu e Eleonora Fabião
}

\author{
Eleonora Fabião \\ Marcio Abreu
}

Eleonora Fabião

Performer e teórica da performance. Professora do Programa de Pós-Graduação em Artes da Cena e da Graduação em Direção Teatral, Escola de Comunicação

da Universidade Federal do Rio de Janeiro.

Marcio Abreu

Dramaturgo, diretor, pesquisador e ator, criou a companhia brasileira de teatro

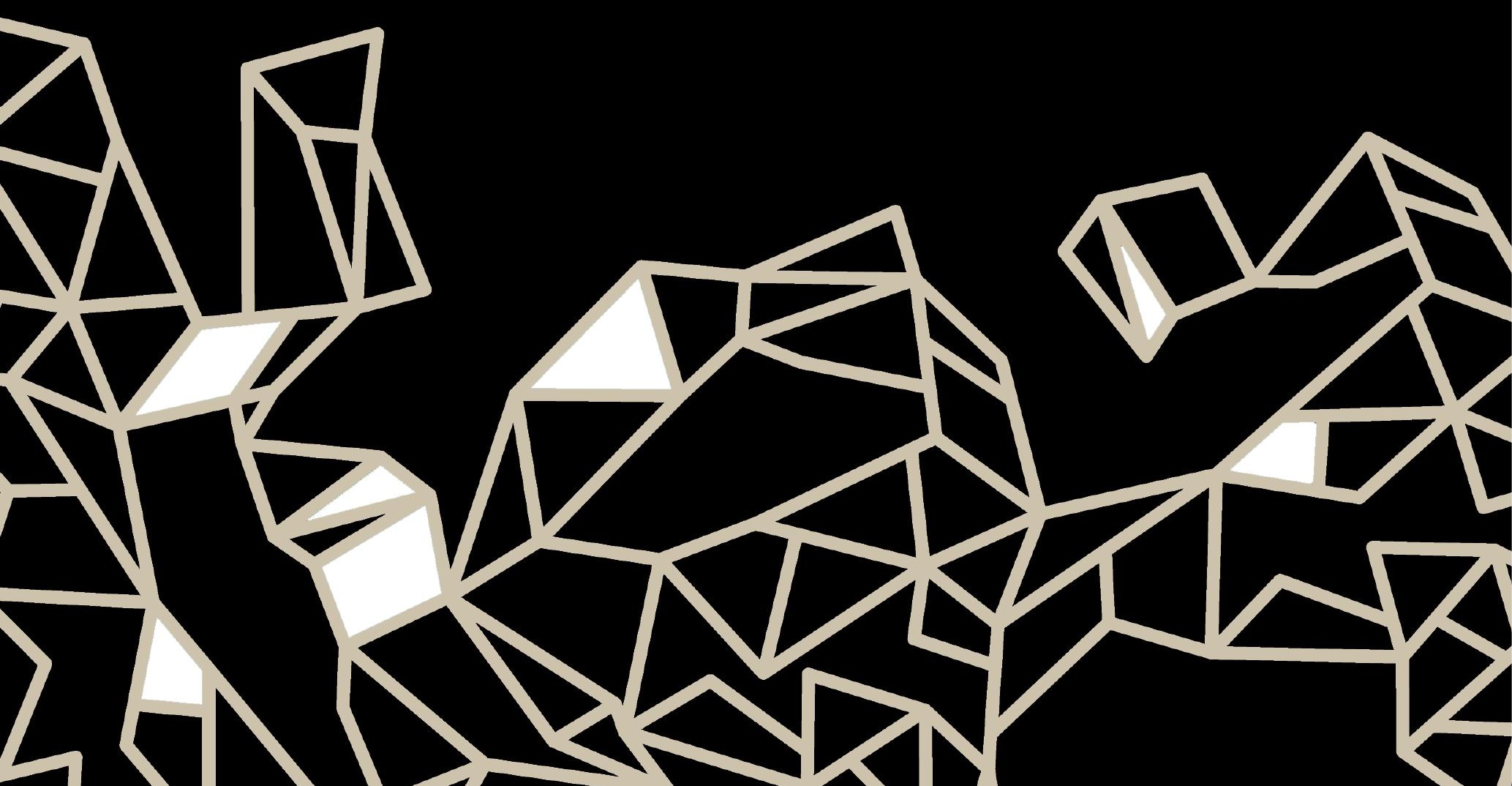




\section{Em 1 de setembro de 2016 14:14, Eleonora Fabiao <ef383@nyu.edu> escreveu:}

meu querido amigo -

hoje estou muito apertada, com dificuldade de escrever, nem sei se consigo, mas querendo estar com você.

em uma linha: ontem a presidente Dilma Rousseff, legitimamente eleita, foi destituída do cargo. nossa democracia está gravemente ferida.

está chovendo muito aqui e estou abraçada a uma garrafa d’água.

precisamos entender agora (nem ontem nem hoje, mas agora) como agir. em tempos de crise tão severa, como não perder o timing da ação mantendo a consistência da reflexão? como agir propositivamente e não reativamente? repito: como agir propositivamente e não reativamente, eis a questão. como inverter a lógica da violência, da desonestidade, do oportunismo, do egoísmo? e, pegando mais fôlego: qual o sentido do político em nosso mundo e momento histórico? o que é fazer política hoje e como fazer? afinal, nada pode ser mais distante do fazer político do que as articulações entre "política", business e crime que sustentam a politicagem dos politiqueiros.

bebi um gole da água. a garrafa é azul, bonita.

estou pensando sobre pensamentos da Hannah Arendt. ela escreveu em agosto de 1950: "O perigo é a coisa política desaparecer do mundo" (O que é política?). essa frase cravou em mim desde a primeira vez que a li. tão perfurante e chocante quanto lúcida e energizante: é um perigo, de fato, a desaparição da "coisa política". da coisa política como compreendida por Arendt. para ela, política é espaço de criação do novo, do inesperado; política é ação plural que potencializa o convívio de diferentes; seu sentido é a liberdade, ou seja, a liberdade não é algo alcançável por meios políticos, mas sim seu conteúdo e sentido original; política é algo que precisa ser permanentemente praticado e partilhado; é algo que se faz na prática e na partilha, como relação, "entreos-homens", entre nós. 
lembro aqui do NÓS, trabalho que você dirigiu com o Grupo Galpão. uma peça que ataca diretamente o sistema nervoso do espectador, como te disse no dia em que assisti no Teatro Ginástico. ela ataca demais os nervos da gente. escrevo esta sentença e sinto NÓS na pele. a Teuda, a "Dilma", o grupo de teatro, o grupo de gente, as explosões, os ruídos de corte, a música, a sopa, a repetição, repetição, repetição, aceleração e queda. cada um de nós empurrados pra lá e pra cá, nos empurrando pra lá e pra cá - você tem que ir embora / é mandatório que você fique. o pertencimento e o não-pertencimento. o lugar de fala e o não-lugar. a identificação e a desidentificação. tão duro dar a ver e ver tanta dissonância. tão necessário. obrigada por cultivar pensamento político e vida política. a você e a todos do NÓS.

levantei, caminhei pelo quarto e me sentei novamente.

é preciso seguir trabalhando, em dobro, se necessário for, colocando no mundo questões e abrindo caminhos. penso que a arte que se sabe e se faz na relação ética e política com o mundo é um espaço privilegiado para colocar questões e propor encaminhamentos. vamos juntos, Marcio Abreu?

pois neste momento, usando este material, a proposta é riscarmos o espaço com uma troca de e-mails ao longo dos próximos dias. poderá ser uma chuva de meteoros ou uma única estrela cadente, certeira. poderá ser uma trajetória curvilínea e uniforme ou uma sinuca interestelar.

me diz.

abraço forte e saudade grande,

Eleonora.

PS: vaga em algum lugar da minha memória uma história que você me contou - envolvia o Tchekhov e um vagão de ostras... me faz lembrar, por favor?

PS2: enquanto tentava me lembrar, cruzou o céu daqui uma citação:

"Talvez essa tradição reforçada pela tecnologia de se pensar sempre em linhas retas e diretas tenha contribuído para uma deficiência na poética ocidental. Palavras, tal como tiros, foram consideradas efetivas na medida em que 
atingiram seu alvo - que sempre foi definido metafisicamente como sendo a compreensão do ouvinte. O sentido das palavras nunca foi considerado como algo relativo à sua maneira de voar. Consequentemente, nunca se desenvolveu no ocidente um corpo de poética-balística dedicado a elucidar as regras de comportamento que governam o voo das palavras e sua representação" (Paul Carter, The lie of the land).

\section{Em 2 de setembro de 2016 18:55, Marcio Abreu <marcioabr@gmail.com> escreveu:}

minha amiga e luz,

esperava vivo suas palavras, um vento fresco de outra parte do mundo, se é que ainda há, em alguma parte do mundo, algum vento fresco que nos leve tranquilos a imaginar outras vidas, lugares, tempos. alguma parte do mundo onde diferença não seja motivo de intolerância. onde espaço para o outro não seja motivo de medo desesperado de perder bens materiais ou privilégios. onde não haja privilégios. onde haja convivência. escuta. silêncio.

por aqui só ruídos.

ensurdecedores. por aqui.

ruídos que reverberam neste day after longo e tenebroso.

eu acordei me sentindo num país estrangeiro. ou melhor. estrangeiro no meu país.

é também como se não estivesse me sentindo dentro da minha própria pele. como se a pele fosse uma roupa de tamanho errado para mim. inadequada. acordei me sentindo apertado. acordei com um aperto. um aperto. como diz, em KRUM, a enormíssima cronópia Grace Passô na voz da mãe angustiada pelo filho.

houve um golpe aqui. fomos golpeados de maneira torpe. e logo eles mostram as garras. parece que tudo que faz sentido vai sendo destruído. 
eu estava em São Paulo no dia do golpe. hoje te escrevo de Belo Horizonte. o Brasil é tão bonito. o Brasil está tão feio. o Brasil é grande. o Brasil está pequeno. o Brasil é sempre e eternamente o país do futuro. hoje o Brasil se resume a esta frase sinistra que foi enfiada na nossa goela desde há muito. por um tempo achei que ela tivesse desaparecido. mas ela reapareceu com força. enfiada na nossa goela. nossa voz está um pouco fraca. estamos entalados. sufocados. cambaleantes. um pouco apáticos. tentando entender como reagir. tarde do dia do golpe.

eu em São Paulo para uma fala sobre o processo de criação do NÓS num encontro organizado pelo CIT-ECUM. chego no local, uma belíssima escola recém-aberta no Brasil, prédio incrível do Isay Weinfeld. vejo o Eduardo Moreira, do Grupo Galpão; me aproximo dele. vamos falar juntos sobre nosso trabalho. sorrimos e nos abraçamos. escuto o barulhinho de recado do whatsapp. num impulso pego o celular e leio: "morremos". a enormíssima cronópia Grace Passô me envia a mensagem. entendi. marejei os olhos. olhei para o Eduardo. disse a ele: "morremos". ele entendeu. novamente nos abraçamos. dessa vez sem sorrisos. olhos marejados. logo depois transcorreu nossa fala e conversa com um público ávido, cerca de 80 pessoas, ávidas por troca, por poesia, por encontros, por conhecimento. lembro que citei você logo no início: "agora vamos ter que fazer tudo o que já fazemos, mas em dobro." por cerca de 2 horas quase esqueço que havíamos morrido. quase lembro que estávamos vivos. que estamos vivos. que vamos continuar. que não vamos retroceder. porque as mudanças dos últimos 15 anos no Brasil estão no corpo das pessoas. e disso não abriremos mão. não abrimos mão dos nossos corpos. lembro que o teatro que busco fazer é ativador de presenças. é provocador de escuta. é convocador de convivências. covivenciar. vivenciar com. isso só acontece se estamos vivos e ali. lembrei que estamos vivos. aqui. e vamos continuar.

noite do dia do golpe.

eu em São Paulo. Sesc Consolação. temporada do NÓS. manifestações contra o golpe ali perto. helicópteros. barulho de bomba. o público chegando ao teatro. ali perto a polícia fascista do Alckmin ataca com violência. os manifestantes, muitos jovens, desviam pela Dr. Vila Nova, rua do teatro. a polícia cerca. tropa de choque. os manifestantes misturam-se ao público que já estava ali. confusão. o Sesc abre as portas para acolher todo mundo. a polícia 
quer invadir o teatro e a área de convivência. do hall do teatro, manifestantes, público, atores, nós todos gritamos "fora Temer". o teatro ainda é um lugar de liberdade. ainda. penso nisso e sinto certo alívio. peço a palavra e oriento a todos para ficarmos ali até a polícia recuar. depois seguiríamos nossa luta. na rua e no palco. assim aconteceu.

noite do dia do golpe.

em São Paulo, ao mesmo tempo em que acontecia o que acabo de relatar, a companhia brasileira de teatro apresentava nossa peça ESTA CRIANÇA num dos CEUs, na periferia da cidade. penso na conversa que tivemos com o público um dia antes, depois da apresentação, lá no CEU Três Lagos, lá pros lados do Grajaú. longe do centro. ponta sul da cidade. três pontes pra lá. penso na abertura e lucidez das pessoas que estavam ali. que falaram sobre a peça, sobre o que sentiram e perceberam, sobre a importância de ter teatro ali e em todo lugar. penso no quanto o teatro fez e faz por mim e por tanta gente. penso que o teatro é tão antigo e tão pequeno. e por isso mesmo tão potente e imponderável. penso na ética do mínimo. penso em Deleuze. penso: "sempre que alguém toma a palavra pode estar ocupando o lugar de outra pessoa que também poderia estar falando". penso nos índios. penso em Pierre Clastres, que no seu livro Sociedade Contra o Estado relata que o chefe indígena, ao fim do dia, deve falar algo à comunidade. durante sua fala, todos fingem não escutar, pois a palavra jamais pode ser confundida com o poder. penso que também busco uma dimensão assim no teatro que faço. a palavra destituída de poder, mas plena de vibração. palavra-corpo. palavrasom. palavra-movimento.

estas palavras aqui querem fazer o movimento de cruzar o céu e te encontrar, mas não sem antes trazer à memória o que você mencionou a respeito de Tchekhov e o vagão de ostras. quando ele morreu num hospital na Alemanha, mandaram o corpo dele de volta à Rússia num vagão para carregamento de ostras. o Gorki, que era muito amigo e profundo admirador dele, escreve uma carta para a própria mulher, na qual narra o que viu e sentiu durante o féretro. havia uma multidão na rua. subiam em árvores, muros e túmulos, falavam alto, riam, destilavam vulgaridades, diziam que ele devia ter ficado rico, que a mulher dele, a atriz Olga Knipper, agora ficaria com o dinheiro, coisas assim. Gorki termina a carta dizendo que o artista, o homem mais sofisticado e generoso de toda a Rússia, havia morrido e que ele, Gorki, queria ter ouvido 
uma só palavra realmente triste, realmente triste. mas ele não ouviu.

Gorki refletia sobre a Rússia naquele momento.

nós refletimos sobre o Brasil neste momento.

beijos daqui.

saudades sempre.

Marcio.

\section{Em 4 de setembro de 2016 07:02, Eleonora Fabiao <ef383@nyu.edu> escreveu:}

meu amigo mar -

que bom receber a sua resposta . não sabia onde você estava . não tinha certeza se a garrafa, as ostras, as estrelas cairiam no seu colo . ainda bem que você está aí . ainda bem . e obrigada por me dar esse tanto daí . estou longe e me custa muito estar longe nesse momento . muito .

precisei que um dia passasse para digerir as suas palavras . que o sol morresse e nascesse . precisei dormir um pouco . sim, morremos . morremos sim . está tudo aberto e ferido . ponto . parágrafo . está tudo aberto para nascermos outra vez . e dessa vez somos muitos morrendo juntos para nascermos juntos outra vez . a sucessão de golpes tem sido realmente tremenda . estamos levando marretadas tremendas . igualmente tremenda é a reflexão que o golpe exige e tremendos os desdobramentos possíveis . tremendos . tremendo . será preciso estar à altura do desafio que se impõe . "preciso " de precisar e de precisão . precisaremos ser precisos . escreveu o Vladimir Safatle na coluna de sexta : acabou o "ensaio geral".

mas fim do ensaio porque é preciso estrear imediatamente ? ou fim do ensaio porque não é o caso de ensaiar ? porque a ação que se quer realizar não se elabora ensaiando?

me pergunto muito sobre ensaiar . por que ensaiar, como ensaiar, onde , quando . me pergunto o que é ensaiar . o que ensaio faz . o que ensaio não faz . qual modo de ensaio faz o que . que sentidos . que corpos . que relações. 
daí te pergunto, no seu entendimento, o que é ensaiar ? como a companhia brasileira trabalha ? cada trabalho exige uma coisa diferente ? acompanhei um pouco o processo de criação do PROJETO bRASIL . fui a Curitiba encontrar com vocês e fizemos aquele workshop, laboratório, experimento . fizemos aquele encontro . numa conversa por telefone, antes da viagem, você me contou como o trabalho estava caminhando e enfatizou : " não se trata de transposição do material lido " . entendi perfeitamente . vocês estavam lendo história social da cultura brasileira, estudando a questão indígena, viajando com o repertório e fazendo uma espécie de trabalho de campo - conhecendo muitas perspectivas, pessoas e lugares, se deixando impregnar . daí eu propus fazermos o que chamei de "Estudo \#1 : com pessoas , palavras , cadeiras , ar , um copo d'água cheio até a borda e movimento " . chamei aquele copo cheio até o limite do limite de "Brasil" . vocês - Marcio , Nadja , Giovana, Cassia , Rodrigo , Ranieri - levaram a cabo o programa ao longo de duas horas e foi incrivelmente belo . o copo estava lá , em cena com vocês o tempo inteiro , e não quebrou . fizeram o esquimbau ali e o copo não quebrou . porém, ontem, depois de ler o seu e-mail, meses e meses depois, eu vi : na tarde do dia do golpe o copo quebrou . estilhaçou . talvez seja preciso fazermos o "Estudo \#2 : com pessoas, palavras, cacos de vidro, ventania , chão de água e movimento " ? ou talvez já estejamos fazendo . Marcio, como anda o PROJETO bRASIL ? como correm as temporadas ? o que essa peça significa na trajetória de vocês ? como vai ?

te conto ainda que ando lendo e relendo o Hélio Oiticica . separei uma citação pra te mandar . inspirado pela Yoko Ono, num texto intitulado Experimentar o Experimental de 1972 , ele escreveu : "Criar não é a tarefa do artista . Sua tarefa é a de mudar o valor das coisas" . nada mais , nada menos . "mudar o valor das coisas". mudar a coisa do valor . mudar o valor do valor.

obrigada por me lembrar da história do Tchekhov, da carta do Gorki , do vagão para transporte de ostras . agora entendo porque o tal vagão anda rondando por aqui . é a combinação morte e movimento . morte e movimento . corpo morto em movimento, coisa que me intriga tanto . nesse caso o vagão não levava ostras , apenas a pérola . era o poeta-médico-pérola cortando o espaço num vagão-ostra e a boçalidade dos boçais boçalando ao redor . e , agora percebo também, pairam por aqui correspondências, cartas, esse jeito de tocar na distância . no dia em que você me contou essa história te contei umas tantas outras . você se lembra ? adoro te contar histórias e escutar as 
tuas histórias . te conto então uma historinha curta antes de ir . antes de enviar esta cartaeletrovirtual . antes de me despedir . digito com os dedos leves e com toda atenção no receio de, sem querer , apertar o enviar antes de acabar de dizer . no receio de que a carta voe antes do ponto final . é sobre uma gaivota . é sobre um homem que fez amizade com uma gaivota e uma gaivota que fez amizade com um homem . ele a chamava de Maria mas não sei como ela o chamava . ela vinha todos os dias comer na mão dele , que ficava aos gritos "Maria ! Maria !" na sacada da casa pela manhã . é muito raro ver amizade entre gente e pássaro solto . mas estes fizeram . pois bem, querido amigo mar, as suas palavras voam alto porque não têm peso de poder .

agora vou abrir a janela e deixar o sol recém-nascido entrar .

abraço forte ,

com e sem olhos marejados ,

Eleonora .

\section{Em 6 de setembro de 2016 12:07, Marcio Abreu <marcioabr@gmail.com> escreveu:}

minha amiga e voz,

eu te leio te ouvindo. setas. silêncios. sorrisos profundos. semblante. cumplicidade. poesia. e ouvir não é apenas o ato fisiológico, acionado pelo mecanismo do corpo físico. ouvir apresenta seus mistérios. ouvir é também ver. há interseções entre os sentidos. e complementações. a escuta tem sido uma espécie de obsessão na minha vida e no meu trabalho. penso nisso diariamente. assim como penso em presenças. ouvir é também estar. nós dois, por exemplo. você em Nova lorque, eu (agora) no Rio. presentes e acionados numa escuta que nos conecta um ao outro em dimensões imprevisíveis de tempo, espaço e de possíveis desdobramentos de tudo isso. por desdobramentos podemos entender reverberações. sua voz reverbera e se faz presente em mim. nós estamos aqui agora.

e seguimos. 
você falava de ensaio. penso-o como plataforma. suporte. experiência. escrita. entendo-o menos como etapa para se chegar a algum resultado e mais como ato criativo autônomo, inscrito na vivência plena de uma circunstância específica. ensaios são o percurso, mas os percursos são valores em si, não são necessariamente tributários de um suposto ponto de chegada. os ensaios são as tentativas, os erros, os desvios, os vislumbres, os excessos, as dúvidas, os acasos, as interferências, os esquecimentos, as convivências, as trocas, os conflitos, as intensidades desmedidas, as precariedades, as leituras, as escavações, as seduções, os entusiasmos, as decepções, os limites afirmados e distendidos, jogos de tensão e distensão. os ensaios são expansões. são pensamento. presença. tempo de vida útil. de duração bastante variável. há trabalhos que ensaio pouco. outros que ensaio muito. outros que não ensaio. gosto de pensar nos irmãos Coen. parece que eles se encontram diariamente para ensaiar. ainda que fiquem em silêncio e não tenham nada a dizer ou fazer. eles estão ali. um diante do outro. isso já é bastante coisa. saber-se em movimento. saber-se cúmplice. saber-se conectado a uma continuidade de trabalho, a um fluxo subterrâneo (novamente Tchekhov) que é uma obra em construção permanente, uma espécie de rio que corre por baixo e que, vez ou outra, jorra pelas superfícies tomando a forma de peças de teatro, performances, atos de fala. a tudo isso chamo de ensaio. e você já disse. a cada vez é diferente. é único. mesmo que haja reincidências, hábitos, costumes arraigados, manias. é sempre diferente, pois o caminho é sempre em direção ao desconhecido. nunca o ensaio é a execução de um projeto totalmente predeterminado. eu tento escapar dessa armadilha. dessa falsa proteção. tento não dar tanto valor ao que criei antes. deixo tudo no nível zero. deixo as coisas e as pessoas me afetarem. busco ser permeável. escuto. costumo trabalhar com interrupções. não gosto da linha reta que vai do primeiro dia até a estreia. trabalho muito nos intervalos. nos buracos. nos vazios. nos "entres." você mencionou o nosso encontro nos inícios do processo de criação de PROJETO bRASIL. o copo cheio, o programa desenhado tão arguta e sensivelmente por você. seu exemplo radical de escuta, presença e implicação na coisa. fizemos uma peça em um dia. e você sabe que depois, numa etapa posterior do processo, adotei o dispositivo. fizemos uma peça por dia durante mais ou menos um mês. e isso foi fundamental. no sentido mesmo de fundamento. de fundações. de base. de sustentação. 
você falava do $P R O J E T O$ bRASIL. eu falava de fundações. percebo que esta peça toca nisso. nas bases. ela articula princípios. e, certamente, vai se desdobrar. já se desdobra, você sabe bem, em projetos como $P R E T O$, que já iniciamos numa residência de criação na Alemanha durante a turnê com PROJETO bRASIL. e a peça segue. fizemos as capitais todas pelas quais passamos durante a pesquisa. agora almejamos os interiores e as periferias. é essencial que isso aconteça. vamos ver. e logo, se tudo der certo, voltamos aos exteriores. a experiência de passar por muitos lugares tem afirmado a potência daquela estrutura dramatúrgica. do teatro como acontecimento inscrito no tempo real e no interstício insuspeito da relação com o outro. nesta peça tentamos ir de um modo mais radical nessa direção. e é forte como as palavras e os atos, tanto em PROJETO bRASIL quanto em NÓS, tomam novas conformações e sentidos nesses tempos de golpe, de crise ética, de barbárie social e de afirmação da ignorância como arma. parece até que fiz as peças depois dos acontecimentos recentes. mas não. elas são anteriores. elas são interiores. elas são vetores da fricção com o nosso tempo, do diálogo com o real, mas no campo da invenção, da construção de língua e linguagem e não da tentativa ingênua de reprodução da realidade. o que será mesmo a realidade? onde ela estará?

invenção-transformação.

em algumas línguas (que não me lembro agora) atribui-se ao artista $o$ ato de transformar. criar talvez tenha raízes cristãs? provável. gosto de pensar que o que faço tem a ver com transformar. sempre em conluio com o desconhecido. algumas palavras que costumo evitar: originalidade, autenticidade, eficácia, funcionamento. e por aí vai. percebo que estamos numa encruzilhada histórica difícil, mas bonita em muitos aspectos. vejo que somos instados, por exemplo, a rever nosso léxico, a refinar o vocabulário, a dar novos nomes às coisas, aos comportamentos, aos sentimentos, às pessoas, aos desejos. a voz a ressoar palavras e sentidos outros, a reinventar esse mundo desgastado, minha amiga.

a você, todo o meu afeto.

seguimos.

conseguimos.

$\operatorname{sim}$. 
beijos.

Marcio.

\section{Em 8 de setembro de 2016 22:38, Eleonora Fabiao <ef383@nyu.edu> escreveu:}

meu amigo real -

muito obrigada pela resposta, pelas respostas, meu querido. fui lendo cada frase e comendo tudo, palavra por palavra. já no final do primeiro parágrafo me ocorreu uma história pra te contar. envolve o João Gilberto. escuta só. estava eu na plateia do Carnegie Hall para assistir a um show solo do João Gilberto - voz e violão. a coisa já andava atrasada e eu temia que ele não viesse. esperava, esperava e enquanto esperava, me lembrei da Gal Costa comentando como era peculiar andar no carro do João. tarde da noite, com a rua quase deserta, quando algum sinal estava vermelho e era possível furar, ele não olhava para os lados e averiguava se vinha algum carro como habitualmente se faz. ele seguia olhando pra frente e freava ou acelerava dependendo do que os seus ouvidos dissessem. ele confiava plenamente na escuta. as janelas do carro sempre abertas e as orelhas parabólicas. aplausos ressoam. entra em cena o inadjetivável João Gilberto. chega quieto, mal dá boa noite, senta-se e começa o que nele já estava começado desde sempre. e, meu amigo Marcio, acontece um show ali que. basta contar que uma música emendava na outra e ele mal dava tempo para aplauso. aplausos, naquele continuum gilbertiano, soavam mais como interrupção do que qualquer outra coisa. o barquinho vai, a tardinha cai, os olhos já não podem ver, sem ela não há paz, não há beleza, é só tons, tons, tons e mais tons. refrãos repetidos mas ligeiramente alterados a cada vez. repetições da diferença. dissonâncias, ou quase, ou não, não sei. boca-sopro, dedos-cordas, linhas melódicas se encontrando e se separando, convergindo e divergindo. o corpo todo na escuta. corpo de telegrafista. de médium recebendo mensagem. a gente lá, em sol maior. ele treinando o ouvido da gente, fazendo escuta na gente, ensinando gente a escutar. foram pelo menos duas horas e meia de transe em velocidade de corrida de cem metros rasos. enfim, não tem explicação. eu só sorria e aguava. no final os aplausos. ensurdecedores. os gritos. alucinados. toda a 
gente aos urros e uivos. a ovação. os ouvidos, pulmões, bocas, explodindo. João Gilberto, que trajava paletó e gravata e estava sentado num banco alto ao longo de todo o show (show? aquilo foi uma liturgia, um sonho, uma aula, um momento de realidade), bom, aquela criatura humana singular (na sua inteligência estrondosa) levantou-se, agradeceu e saiu pela coxia lateral. caso é que enquanto ele andava palco afora, eu tive uma visão. eu vi: João era uma grande orelha. o corpo dele todo era uma orelha. as costas meio curvadas, o rosto um tanto voltado pro chão, o violão rente ao corpo: o homem e seu violão tinham a forma de uma orelha. uma orelha com pernas. e a orelha gigante caminhou. partiu. foi. foi alucinante. tão bonito. mas tão bonito. "o que será mesmo a realidade? onde ela estará?" (Marcio Abreu, e-mail do dia 6 de setembro de 2016).

me passa um copo por favor? Marcio, me fala um pouco sobre amizade? amizade. amizades. me conta um pouco sobre a companhia brasileira, sobre o tipo de amizade que o fazer teatro proporciona? te pergunto também: como acontecem as relações em trabalhos como KRUM, por exemplo, com mais artistas, com os colaboradores da cbt? e com o Grupo Galpão, um grupo com 34 anos de existência? enfim, são muitos tipos de amizades. podemos chamar assim? e muitas as questões afetivas, éticas, artísticas e políticas envolvidas. me passa outro copo, meu amigo? e desculpa tanta perguntação mas tenho muita vontade de te ouvir. fico pensando também que você mudou de cidade num momento crítico da vida e essa deve ter sido uma questão importante naquela época, não?

lendo seu e-mail também me ocorreu que te perguntei sobre trabalhos específicos, modos de ensaio, andamento de temporada, mas não sobre a trajetória como um todo, em perspectiva, na duração. como as peças vêm se desdobrando ao longo do tempo? por exemplo: escuto algumas, digamos, citações de VIDA, OXIGÊNIO e PROJETO bRASIL em NÓS. quais são as tuas fascinações, as fomes que não são saciadas, os versos mais amados, os labirintos mais frequentados, os vícios?

me passa mais um copo? quero partilhar com você um assunto que faz tempo me interessa. e mais outro, por favor? a fisiologia do ouvido. talvez o ouvido seja uma das partes mais impressionantes do corpo humano. não, bobagem dizer isso! todas as partes e todos os todos do corpo são tão impressionantes! aliás, já nem sei mais o que é corpo. tão. e imponderável. 
mas escuta só. há uma membrana chamada "janela oval" que leva à cóclea. a cóclea, localizada no ouvido interno, é um tubinho ósseo em forma de espiral, um caracol mesmo, com duas voltas e meia e cheio de líquido. é nesse caracol que a vibração sonora se transforma em impulso nervoso a ser transmitido ao cérebro. é onde a energia mecânica é convertida em sinal elétrico. caracol debaixo dos cabelos. são centenas e centenas de células ciliadas (gosto da palavra "ciliadas", ou ainda, de palavras ciliadas) que vibram de acordo com o som que nos chega. para escutar, vibramos. para escutar um ritmo, nos ritmizamos. nossos ouvidos ciliados piscam. li também que quando nascemos a cóclea já tem seu tamanho definitivo. ela não cresce com o passar dos anos. surpreendente, não? me passa mais um copo? ligado à cóclea está o "sistema vestibular" responsável pelo equilíbrio do corpo. ao conjunto vestíbulo e cóclea chamam "labirinto" por conta da complexidade anatômica dos canais. pois, Marcio Abreu, caminho por essas curvas e labirintos em equilíbrio precário te escutando sobre a arte de escutar. ajeito meu dial, afino a frequência e encontro uma frase que diz assim: um ato de fala que não seja também ato de escuta não sintoniza. e mais: a arte de dirigir como ato de escuta exige percorrer muitos labirintos e experimentar corajosamente com a precariedade do equilíbrio. para o ator não será muito diferente: a arte de atuar como ato de escuta exige percorrer muitos labirintos e experimentar corajosamente com a precariedade do equilíbrio. e para o espectador também não me parece que haja grande diferença: a arte de espectar como ato de escuta exige percorrer muitos labirintos e experimentar corajosamente com a precariedade do equilíbrio. mas isso quando ouvidos falam para ouvidos. espiraladamente.

na escuta,

e cheia de novos copos para fazermos o que quisermos com eles, sua, sim, Eleonora. 


\section{Em 16 de setembro de 2016 03:25, Marcio Abreu <marcioabr@gmail. com> escreveu:}

escuta essa, minha amiga,

aqui no Japão pode fumar em lugares fechados, mas não pode fumar andando na rua. estou aqui no KIAC - Kinosaki International Arts Center. incrível! ontem houve um debate depois da peça Montanha, e me chamou muito a atenção a liturgia da escuta por aqui. não há falas atropeladas, não há falas nem mesmo simultâneas. há fala, silêncio e escuta. ainda não sei o que pensar sobre isso. o nível de atenção e concentração é muito alto. mas também é alto o nível de enquadramento e funcionamento dentro de padrões nos quais a comunidade existe. é bastante paradoxal. belo e asfixiante ao mesmo tempo. é doce e gentil. mas pode ser duro também. aqui tomei banho quente com águas vindas do centro da terra. é um vilarejo onde há muitos onsens, que são umas casas de banho com essa água ancestral muito louca que sai do meio das pedras desse pequeno pedaço de mundo. encravado nas montanhas dessa ilha a 12 horas de fuso do nosso Brasil quase afundado, à deriva, naufragante. é difícil estar longe. preciso confessar. tenho feito esforços pra me concentrar nas coisas aqui, nas leituras, olhares, experiências e aberturas para o novo (pra mim). tenho conseguido a duras penas. hoje fui pedir ao buda num templo daqui. quem sabe ele me ajuda. acendi 1 vela fina com escrita japonesa vermelha e 2 incensos finos verdes. botei fé. caminhei na manhã quente e calma daqui. voltei pra residência e vim conversar com você.

nossa amizade veio nascendo de mansinho. lembro de você indo ver OXIGÊENIO no Espaço Sesc, em Copacabana, e aí nos falamos depois. foi bonito. é.

\section{$(\ldots)$}

hoje já te escrevo de Tokyo. cidade sem fim. nem começo. cidade contínua. cidade fluxo. várias cidades numa só. nunca me imaginei no Japão, minha amiga. e, sem imaginar, de repente, me vejo aqui. e me vejo aí, transportado pela seta interestelar, numa trajetória curvilínea. hoje estou muito apertado, com dificuldade de escrever, nem sei se consigo, mas querendo estar com você. 
difícil falar sobre amizade. amizades. elas estão por trás de tudo.

\section{$(\ldots)$}

essas reticências acima, entre parênteses, significam pausas de tempo. com intervalos de horas ou dias. eu estou atravessado por muitas intensidades aqui em Tokyo. sei que temos o prazo de até o dia 20 pra enviar nossa correspondência. hoje recebi a notícia da morte do Domingos Montagner, uma ator tão bonito do teatro em São Paulo. uma figura tão doce. a morte de um artista é sempre violenta.

logo vou falar sobre amizade. logo vou falar mais sobre tudo o que nos une e sobre o que não sei. por enquanto te envio essas linhas tortas e repletas de vazios. vou continuar. vou continuar. vou continuar. vou continuar. vamos continuar. vamos. nós vamos. continuar. continuar. continuar. continuar. nu. ar. ar. no ar. nu no ar. no ar. no ar. no ar. ar. ar. ar. ar. ar. ar. ar. ar. ar. nu. estou nu. no ar. ar. ar. ar. ar. ar.

$(\ldots)$

\section{Em 17 de setembro de 2016 09:20, Eleonora Fabiao <ef383@ nyu.edu> escreveu:}

para o Marcio no Japão -

queria demais estar contigo agora.

estamos juntos aqui.

abraço e amor,

Eleonora.

PS: ontem ouvi dizer de uma montagem de um grupo chamado Theater Mitu. Um "Hamlet" em que Ofélia, a personagem-Ofélia, é um quarto. 


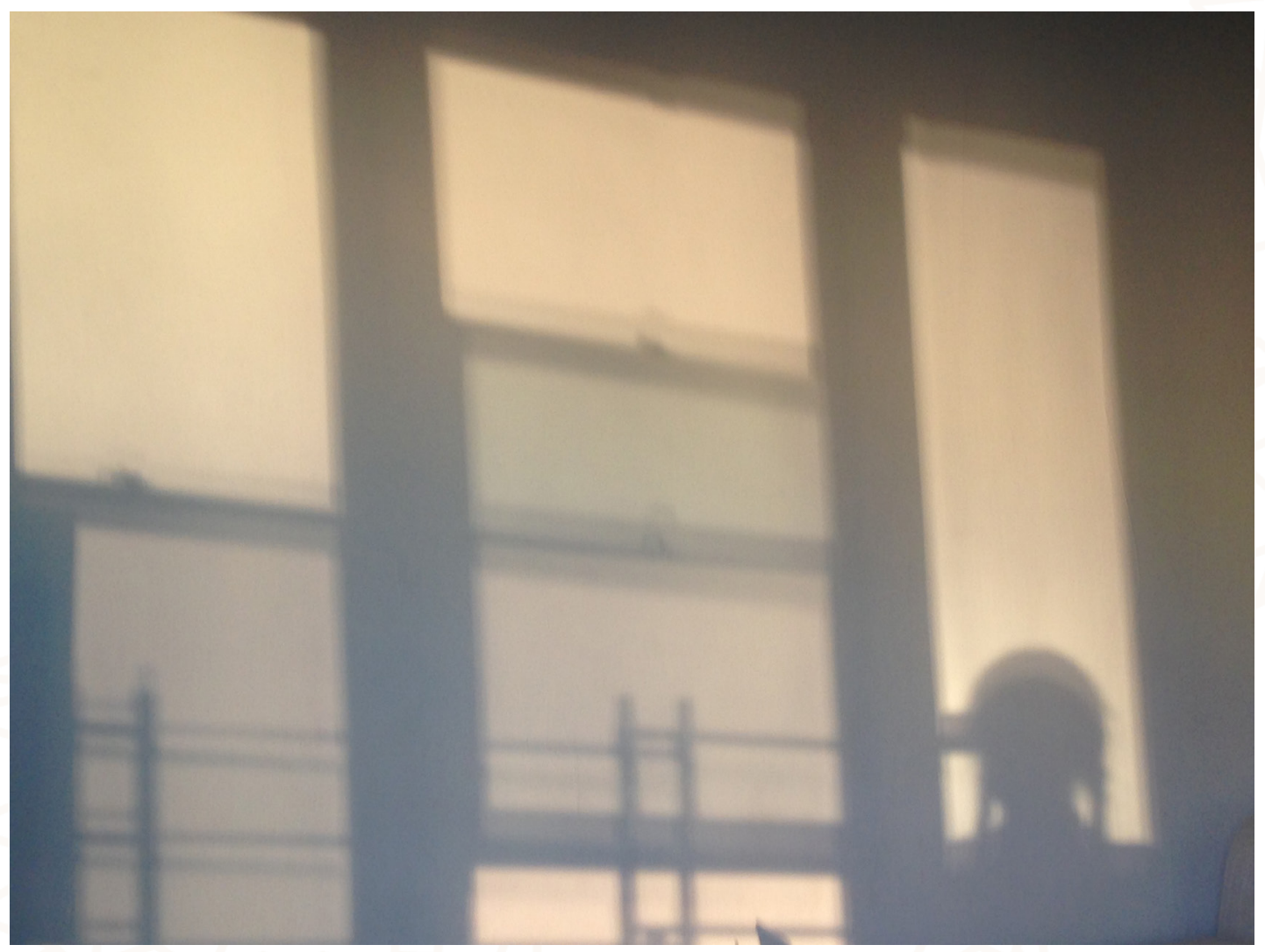

Em 18 de setembro de 2016 01:33, Marcio Abreu <marcioabr@gmail. com> escreveu:

para a Eleonora nos EUA.

Ofélia como um quarto é uma ideia desconcertante. a desmedida do amor e da inadequação representadas num quarto.

faz pensar.

te escrevo de um quarto. décimo andar. hoje decidi ficar bastante tempo dentro do quarto. já aprendi o que é preciso fazer se tiver terremoto.

penso nos amigos. eu dizia que as amizades estão por trás de tudo. de certa maneira a vivência prática do teatro demanda gestos de amizade. fazer teatro é, quase sempre, dar a mão a alguém e ir rumo ao desconhecido. e no caminho não é incomum que a gente se torne amigo. convive-se muito. muitas horas. em circunstâncias as mais variadas. a gente se vê na fragilidade e na potência. na 
dúvida e na conviç̧ão. na pausa e no movimento. no claro e no escuro. a gente se vê no escuro. caminha no escuro. fica juntos em silêncio. é muito difícil ficar em silêncio junto de alguém. ou de várias pessoas. há um gesto de amizade nisso.

aqui no Japão reparei que as pessoas ficam muito em silêncio. juntas. na plateia do teatro, enquanto o público entra e espera a peça começar, não há conversa. todos quietos. esperando. não sei se é amizade. provável que não. talvez seja pudor, solenidade ou medo de incomodar o outro, sei lá. ou apenas comportamentos condicionados por uma cultura diferente da minha e aí fico achando isso diferente. diferente. essa palavra tão estranha.

em geral somos amigos porque admiramos as nossas diferenças, apesar de reconhecermos as nossas semelhanças.

minhas amizades no teatro são muitas. enão significa que haja tanta convivência fora do trabalho. às vezes há. mas isso não é regra. a companhia brasileira foi se formando organicamente, por afinidades. a Nadja Naira chegou pra me ajudar com a luz do VOLTA AO DIA... , a Giovana Soar, um pouco depois, pra ajudar na produção dessa mesma peça. Ainda depois veio a Cássia Damasceno, também pra ajudar na produção na época do VIDA, e todos os parceiros, o Ranieri Gonzales, ator em tantos dos nossos trabalhos, o Rodrigo Bolzan, que entrou substituindo o Rodrigo Ferrarini e que é um grande parceiro, assim como o Rodrigo e a Renata Sorrah, a Grace Passô, o Luis Melo, a Cris Larin, a Inez Viana, o Danilo Grangheia, o Edson Rocha, tantos artistas incríveis que atravessam nossa história de maneira tão fundamental. eu tento sempre que a companhia seja uma estrutura aberta, dinâmica e permeável. temos um núcleo que é mais fixo, mas sempre afirmando o espaço daqueles artistas que colaboram e que são também a companhia. nesse sentido é importante ter um fluxo de trabalho contínuo, um repertório posto em ação. vivo. é importante estar também em diálogo com outras instâncias artísticas. trabalhamos com frequência nos deslocamentos. felizmente temos conseguido levar as peças a várias cidades e, assim, conhecer as pessoas e se deixar afetar por elas.

hoje é dia 18. ainda temos 2 dias. logo mais escrevo mais.

teu.

Marcio. 


\section{Em 18 de setembro de 2016 12:11, Eleonora Fabiao <ef383@nyu.edu> escreveu:}

meu amigo querido -

uma bomba em Chelsea. bairro ao lado aqui de casa. na Rua 23 com Sexta Avenida, a Avenida das Américas. as Américas. 29 feridos. ato intencional.

lembrei das explosões em NÓS. duas explosões. uma quase no final da peça. e mais os balões em PROJETO bRASIL. tá tudo ressoando.

sirenes. encontraram uma segunda bomba. caseira. panela de pressão talvez com pregos dentro? mais sirene. a segunda não foi detonada. diz que colocam duas bombas pra explodir a segunda mais tarde, quando junta mais gente, quando chega socorro.

copos quebrando. copos quebrados. os copos. os copos.

nestes dias estou muito ligada a você. num e-mail anterior você falou "percebo que estamos numa encruzilhada histórica difícil, mas bonita em muitos aspectos. vejo que somos instados, por exemplo, a rever nosso léxico, a refinar o vocabulário, a dar novos nomes às coisas, aos comportamentos, aos sentimentos, às pessoas, aos desejos. a voz a ressoar palavras e sentidos outros, a reinventar esse mundo desgastado, minha amiga"te escuto, Marcio. te escuto, meu amigo escuta. e eu, em outro e-mail, falava de golpes tremendos. tremendo. as palavras tremendo. os sentidos tremendo. as células ciliadas tremendo. a membrana da janela oval ciliando e nada fazendo sentido. a perda dos sentidos. a falta de sentido. a falta de sentido da violência. a absoluta falta de sentido da violência. e a violência do sentido. e o esgotamento do sentido. e o trabalho incessante de elaboração de novos e antigos sentidos. sentidos de acordo com as circunstâncias. e as circunstâncias se mexendo. sem parar. e tremendo. e então o desfazimento dos sentidos. as sensações. os refazimentos. a desfazeção. a invenção. e mais as obviedades todas. e as normatividades todas. enfileiradas no refeitório. e os surtos. os sustos. as suspensões de sentido. vidraças tremendo. prédios tremendo. mais sirenes. hoje vai ser assim. o dia todo. seguimos. seguimos. tenho uma necessidade imensa de abrir as coisas, abrir os sentidos, abrir. abrir. abrir. seguimos. 


\section{$(\ldots)$}

me abraça,

Eleonora.

\section{Em 18 de setembro de 2016 13:39, Marcio Abreu <marcioabr@gmail. com> escreveu:}

minha amiga querida, aqui vai meu abraço demorado. em silêncio, como você bem sabe fazer. você. uma mulher silente. concentração e escuta orientais. iminência de leoa. cabelos de leoa. última vez que nos vimos teus cabelos longos. belos. aqui vai meu abraço demorado, sabendo que os corpos contam muito. o corpo presente é necessário. sabemos disso. o corpo implicado no ato. mesmo distantes nos sabemos presentes. também eu, nestes dias, tenho estado muito ligado a você. sempre um copo até a borda: a inteireza, sempre, em tudo. a coragem. a delicadeza / força. o silêncio. aqui vai meu abraço demorado. pego um copo transparente. encho de água até a borda e bebo. brindo com você agora a tudo o que pode ser transformado e inventado. brindo aos corpos presentes. brindo à diferença. brindo ao outro. aos deslocamentos, a tudo que se permeia, se penetra.

lembro do lançamento do teu livro amarelo em Belo Horizonte, na sede do Espanca! cheguei atrasado e tinha densidade no ar. tudo era concreto. eu cheguei e, por acaso, havia silêncio. de novo ele. e tudo existia na base da essencialidade. quero dizer com isso que cada elemento no espaço era perceptível em seus contornos. tudo tinha contorno. cada palavra emitida por você. cada acontecimento singular, como aquele homem da rua que penetrou o espaço e você fez o movimento de escuta, acolhida e seguiu. as pessoas ao redor de você. uma vibração louca. muito forte. e depois o percurso do livro que se desloca pela cidade, afirma a dimensão pública da arte. livro pra não se vender. livro pra girar. a gira. a roda. o mundo. ali.

por isso quero te dizer que o mundo não são essas bombas e sirenes que você escuta agora vindas de Chelsea. o mundo também é o silêncio compartilhado na sede do Espanca! aquele dia em Belo Horizonte, não faz muito tempo. o 
mundo é seu livro que gira. o mundo gira. e vai mudar. nós tentamos mudá-lo um pouco. todos os dias. aqui vai meu abraço demorado.

bom, você falou das bombas e eu me lembrei que quando estávamos no processo de tradução, adaptação e dramaturgia de OXIGÊNIO descobri que em russo há um enorme vocabulário pra tudo o que é golpe. o léxico de guerra e violência é grande. dá pra entender, quando pensamos na história daquele país. no texto original havia várias palavras diferentes pra definir como o jovem Sacha tinha golpeado com uma pá e matado a jovem Sacha, por quem ele tinha um amor louco. na tradução para o francês, e em consequência para o português, a palavra esquartejar dava conta de tudo. uma só palavra. no russo havia muitas palavras, praticamente intraduzíveis. a violência é muitas vezes intraduzível. assim como é intraduzível o amor. OXIGÊNIO é uma peça repleta de amor e violência. uma peça política. uma estrutura em 10 composições manifestas. uma peça sonora, como tudo o que faço. penso muito como música. muitas vezes nos ensaios eu apenas ouço. de olhos fechados. outras deixo de ouvir e apenas vejo. outras estou ali com tudo, inteiramente de dentro. é sempre de dentro. é sempre aqui e agora. OXIGÊNIO começa com a frase (rubrica?): "Este é um ato que deve acontecer aqui e agora".

toda a dramaturgia que faço tem o compromisso com certa dimensão do presente. tanto em textos que escrevo como em textos que adapto, releio ou articulo de alguma forma. toda a dinâmica dramatúrgica em NÓs, por exemplo, é motivada por um pensamento que ativa a presença daqueles 7 atores em cena. em PROJETO bRASIL, o desafio maior, na sequência de discursos verbais e não verbais, é o de encarnar a escuta e penetrar a experiência de construção de imagem. ouvir não ignora o corpo. imagem não é uma instância da qual estamos fora. o corpo está implicado. em tudo. KRUM é uma peça elaborada nesta base. corpos agindo no coletivo. peça com personagens, mas num processo no qual todos os atores e atrizes misturaram-se num fluxo de falas, ações e invenções sem fronteiras ou donos.

não queremos fronteiras nem donos, minha amiga. reverberamos bombas no teatro porque não queremos as bombas que explodem nas ruas, matando gente. estudamos vocabulários de guerra porque não aceitamos a violência. falamos de golpe porque estamos no meio de um que já vislumbrávamos e que não suportamos. criamos pra transformar. e já falávamos que em alguma língua que não sei qual atribui-se ao artista o ato de transformar. 
"pra onde a gente vai?" diz o Eduardo Moreira em NÓs. é também o que eu me pergunto agora. e sei que há um turbilhão gerador de movimento intenso. eu sugiro aqui que o primeiro seja o movimento de parar. o segundo o movimento de abrir.

seguimos

$(\ldots)$

te abraço.

Marcio.

\section{Em 20 de setembro de 2016 14:31, Eleonora Fabiao <ef383@nyu.edu> escreveu:}

meu querido -

chegamos no dia 20 e o dia 20 chegou em nós. movemos movidos movendo. movimento permanente no movimento permanente. há explosão, tremor e revolta. há firmeza, resistência e serenidade. "resistência" no sentido de oposição e de fôlego. é preciso muito fôlego para que a ação seja propositiva e não reativa. escrevi sobre isso lá no primeiro e-mail e volto a escrever porque me parece muito importante. muito.

no momento do aperto, a arte de abrir espaço. espaço é algo que se produz, que se faz, que se cria, se secreta. espaço é resultante de agenciamento. marcio, você faz muito espaço com a sua arte, marcio. te agradeço imensidade por isso. sua arte inspira energiza ativa deslancha move. e quando os campos de ação estão tão perturbadoramente enrijecidos, tão densamente peganhentos, é preciso mais arte do que nunca. quando aperta o cerco, é preciso muita arte. fazer vida íntegra. determinação e ética. sim sim sim e sim.

outro dia vi o trabalho de um artista que construía barricadas na rua com obras de arte, com quadros e esculturas. assim se manifestava nas manifestações. encontrou o seu jeito de transformar. não esqueci e não esquecerei. é preciso lembrar permanentemente no movimento permanente. lembrar de lembrar. lembrar de lembrar. anoto num papelzinho e espeto na parede. na parede já tem outro papelzinho espetado. nele está escrito o título de uma ação que ainda 
não sei como será. "tão tanto que muito é pouco". dessa vez o título chegou primeiro. engraçado. isso te acontece de vez em quando? vai ver que essa ação é só um título mesmo. daí se chamaria verso? deixa que o tempo resolve.

penso que experimentação é um q muito importante da questão. seguir experimentando, ou seja, abrindo espaço. experimentar envolve uma espécie de não-saber convicto. ou a convicção de que o sentido é um fazer. em outras palavras: a gente passa da questão de se isso faz ou não faz sentido para a ação de fazer sentido. fazer sentido. a cada vez. um trabalho trabalhoso trabalhento trabalhoado trabalhárduo trabalhífero tratorifíldico e infinitamente belo esse da experimentação.

pois sigamos. experimentando. nos experimentando. experimentando um ao outro. que, evidentemente, não se trata de testar uns aos outros. tão longe disso. me dá até vontade de rir. que os testes fiquem para os que gostam de testar e ser testados. de julgar e ser julgados. a amizade é a prova dos nove. a amizade como um referente para pensar e fazer política. a amizade política como uma espécie de coluna vertebral de corpos coletivos. entre nós, os concidadãos, dialogismo, atenção, reciprocidade, cooperação, respeito, princípios básicos da amizade. a amizade política como um princípio de cidadania.

seguimos e seguiremos experimentando a distância e fora dela. porque, claro, há distância mas, claro, não há distância nenhuma. há pactos. coexistência. mistura. implicação consciente e inconsciente. desejada e indesejada. coerência e incoerência. dição e contradição. expansão e contração. atos de fala e atos de escuta. atos de fala cheios de escuta e atos de fala vazios de escuta. ou seja, atos de fala e atos de falação. e há teatro. felizmente. há krum nesta criança, vida e oxigênio em nós e projeto brasil. há movimento permanente no movimento permanente. e palavras. palavras que podem ser espelho muro caixa vetor projétil ferramenta chave chiclete pílula leque dinamite diamante motocicleta túnel tapa beijo gaivota mosca campo grampo ou grão. que podem ser tudo e ser nada. ser quase-nada e quase-tudo. quase-quase. ser e não ser. lapavras, vrapalas, pavralas. umas espécies de larvas. as palavras são essa. assim. escuta essa. massa sem massa. movimento? 
gaivota vagão pérola estrelas balística. japão chelsea rio de belo janeiro são horizonte. copo corpo bomba e teatro. saguão polícia incenso sirene mar joão violão. fumar em lugares fechados e fumar em lugares abertos. encruzilhada léxico línguas nomes enorme. escuta cóclea ciliada labirinto pulmões. ensaios tentativas erros desvios vislumbres excessos dúvidas acasos interferências esquecimentos convivências trocas conflitos intensidades desmedidas precariedades leituras escavações seduções entusiasmos decepções limites afirmados e distendidos. templo silêncio fé botei fé buda nu nu nu no sol ar ar ar voar. janela do carro. janela de casa. janela oval. vidraças tremendo. fundações interiores periferias. sem dentro e sem fora. é sempre de dentro. imagem não é uma instância da qual estamos fora. manifestantes jovens. agentes. amigos. penso no quanto o teatro fez e faz. penso no quarto. rodrigo renata grace galpão ofélia yoko tokyo brasileira domingos hélio de anton $\mathrm{e}$ gorki. marcio marcio marcio e marcio. e por cerca de 2 horas quase esqueço que havíamos morrido. penso muito como música. é uma peça sonora, como tudo que faço. barulhinho de recado do whatsapp. explosão. silêncio. cabelo solto. abraço triste. abraço demorado. e apertado. abraço às gargalhadas. carne sacudindo carne. golpe. marretada. quebrando quebrado quebrou. fazse outro. faremos outros. faremos em dobro se preciso for. ligados ligados ligados. me liga te ligo. me gira te giro. o livro amarelo gira. forma é movimento. amor. eleonora.

Recebido em 11/10/2016

Aprovado em 31/10/2016

Publicado em 21/12/2016 